9

\title{
Cognitive health after menopause: Does menopausal hormone therapy affect it?
}

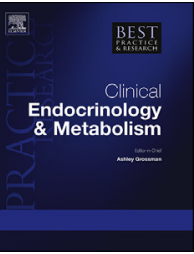

\section{Petra Stute, MD, Board-certified Gynecologist and}

Obstetrician, Board-certified Gynecological Endocrinologist, Reproductive Medicine Physician ${ }^{\text {a, *, }}$, Johanna Wienges, MD, Medical Student ${ }^{\mathrm{a}}$, Anne-Sophie Koller, MD, Medical Student a, Christina Giese, MD, Board-certified Gynecologist and Obstetrician $^{\mathrm{b}}$, Wiebke Wesemüller, MD, Board-certified General Medicine Physician ${ }^{\mathrm{C}}$, Heidrun Janka, MSc, Master of Arts Library and Information Science ${ }^{\mathrm{d}}$,

\section{Sabrina Baumgartner, MD, Board-certified Gynecologist and Obstetrician $^{\mathrm{e}}$}

\footnotetext{
${ }^{a}$ Department of Obstetrics and Gynecology, Inselspital, University of Bern, Friedbühlstrasse 19, 3010, Bern, Switzerland

${ }^{\mathrm{b}}$ Department of Obstetrics and Gynecology, Evangelisches Diakoniekrankenhaus Freiburg, Wirthstrasse 11, 79110, Freiburg Im Breisgau, Germany

${ }^{\mathrm{c}}$ Aerzte Am Boulevard, Hauptstrasse 54, 8280, Kreuzlingen, Switzerland

d Medical Library, University Library Bern, University of Bern, Baltzerstrasse 4, 3012, Bern, Switzerland

e Department of Obstetrics and Gynecology, University Hospital of Zürich, Frauenklinikstrasse 10, 8091, Zürich, Switzerland
}

Abbreviations: AD, Alzheimer's disease; EMAS, European Menopause and Andropause Society; EPT, Estrogen Progestogen Therapy; ET, Estrogen only Therapy; IMS, International Menopause Society; MHT, Menopausal Hormone Therapy; NAMS, North American Menopause Society; NICE, National Institute for Health and Care Excellence.

* Corresponding author. Gynecologic Endocrinology and Reproductive Medicine, University Clinic of Obstetrics and Gynecology, Inselspital Bern, Friedbühlstrasse 19, 3010, Bern, Switzerland. Fax: +41 31-632-1332.

E-mail addresses: petra.stute@insel.ch (P. Stute), christina.giese@diak-fr.de (C. Giese), wiebke.wesemueller@hin.ch (W. Wesemüller), heidrun.janka@ub.unibe.ch (H. Janka), sabrina.baumgartner@usz.ch (S. Baumgartner). 


\section{A R T I C L E I N F O}

Article history:

Available online 17 August 2021

Keywords:

menopause

menopausal hormone therapy

dementia

Alzheimer's disease

prevention

counseling tool
Dementia is a pandemic chronic non-communicable disease. 10 in 100 women above age 65 will be diagnosed with dementia, primarily Alzheimer's disease (AD). Apart from age and hereditary risk factors, there are multiple acquired risk and protective factors. So far, Menopausal Hormone Therapy (MHT) is not recommended as preventive measure. A systematic literature search on MHT and dementia risk and MHT and cognitive performance in demented women, respectively, was performed. Two recent meta-analyses identified 18 and 16 studies analyzing the impact of MHT on dementia/AD risk. Our systematic literature search identified eight additional original articles. The majority of studies found a risk reducing impact of MHT by $11-33 \%$. However, results may vary depending on MHT type, age at initiation and study design. For example, the Women's Health Initiative Memory Study (WHIMS) reported an approximately 2-fold increased risk of dementia/Alzheimer's disease if MHT comprising conjugated equine estrogens and medroxyprogesterone acetate was initiated in predominantly comorbid postmenopausal women above age 65. In general, MHT displays a beneficial effect on several dementia risk factors and also augments some protective factors. Accordingly, clinicians can be reassured that MHT can be safely prescribed in the context of cognition in women free of dementia. However, MHT is not indicated for cognitive improvement in demented women. International scientific guidelines on MHT and dementia should consider incorporating most recent data.

(C) 2021 The Authors. Published by Elsevier Ltd. This is an open access article under the CC BY-NC-ND license (http:// creativecommons.org/licenses/by-nc-nd/4.0/).

\section{Introduction}

Dementia is a pandemic chronic non-communicable disease (NCD). Dementia is characterized by impairment of cognition, mostly involving memory and at least one other cognitive domain (language, visuospatial, executive function). Until today, there is no effective single intervention for dementia prevention and treatment, respectively. Thus, the focus lies on intensive risk factor modification, especially during midlife (age 45-65 years). About 35\% of dementia cases are thought to be attributable to a combination of nine potentially modifiable risk factors (low educational attainment, midlife hypertension, midlife obesity, hearing loss, late-life depression, type 2 diabetes mellitus (T2DM), physical inactivity, smoking, social isolation) [1]. Alzheimer disease (AD) is the most common cause of dementia. Without doubt, there are sex differences in $A D$. For example, according to a recent review, men die faster with AD, more women live with AD, and both sexes show similar risk of developing $A D$ until advanced ages when women show increased risk, respectively [2]. In Europe, approximately $10 \%$ of women above age 65 will be diagnosed with AD at some point [3]. It is still an ongoing controversy if and to which extent the age and menopause associated decline in endogenous steroid hormone exposure has an impact on AD development and disease course, and if menopausal hormone therapy (MHT) can be used for $A D$ prevention. As current guidelines from international scientific societies have not been updated for some time (NICE in 2015 [4], IMS in 2016 [5], EMAS in 2016 [6], NAMS in 2017 [7], the goal of this systematic review was to 1) update the scientific evidence on the impact of MHT on dementia risk, and to 2 ) provide a counseling tool to support daily clinical practice (personalized medicine). 


\section{Material and methods}

Information sources and search strategy

Complex literature searches were designed and executed by a medical information specialist (HJ) for the following information sources to identify all potentially relevant documents on the topics: 1) Medline (Ovid) (incl. Epub Ahead of Print, In-Process \& Other Non-Indexed Citations, Medline Daily and Ovid Medline Versions (1946-February 26, 2021), 2), Embase (Ovid) (1974-February 26, 2021), 3) PsycInfo (Ovid) (1806-February 26, 2021), 4) Cochrane Library (Wiley) (1996-February 26, 2021), 5) Web of Science (Clarivate) (1900-February 26, 2021), and 6) ClinicalTrials.gov (NLM), respectively.

Initial search strategies in Medline/Ovid were drafted for four topics (1) Impact of menopause on risk for affective disorders: depression, anxiety, 2) Impact of menopause on cognition: in general, MCI risk, dementia risk, 3) Impact of MHT on affective disorders: depression, anxiety, 4) Impact of MHT on cognition: in general, risk of $\mathrm{MCI}$, dementia) and tested against a list of core references to see if they were included in the search results. After refinement and consultation, complex search strategies were set up for each information source based on database-specific controlled vocabulary (thesaurus terms/ subject headings) and textwords. Synonyms, acronyms and similar terms were included in the textword search. No limits have been applied in any database considering study types, languages, publication years or any other formal criteria. The searches have been run in the medical bibliographic databases Medline, Embase and the Cochrane Library, as well as PsycInfo, Web of Science and ClinicalTrials.com, a database of clinical trials. The search dates were March 2nd and 3rd, 2021. The main search concepts identified were "menopause" (including pre-, peri- and post-menopause) for topics 1 and 2, "hormone replacement therapy" for topics 3 and 4", "depression" and "anxiety" for topics 1 and 3, and "risk of dementia" and "mild cognitive impairment" for topics 2 and 4 . In addition to electronic database searching, reference lists and bibliographies from relevant publications were checked for relevant studies. The final detailed search strategies are presented in supplementary file 1.

\section{Eligibility criteria}

Articles were included if women were postmenopausal and taking MHT. MHT was defined as use of systemic estrogens only (ET), systemic estrogen progestogen therapy (EPT), or tibolone at any dosing schedule and dosage. Studies on systemic androgen therapy or only vaginal estrogen therapy were excluded. All original studies, systematic reviews and meta-analyses were included, while editorials, letters, and comments were excluded.

\section{Study selection and data collection process}

All identified citations were imported into EndNote and duplicates were removed. Title and abstract screening was performed by two co-authors (AK, SB) using EndNote and tested against the inclusion criteria. In case of disagreement the fulltext article was read to allow for decision making. Then, fulltext screening of all identified abstracts was carried out by four co-authors $(\mathrm{CH}, \mathrm{JW}, \mathrm{SB}, \mathrm{WW})$ with each article being checked for relevance twice. Any ambiguity was discussed among all authors. Data extraction from all selected articles was performed by PS.

\section{Data outcomes}

Systematic database searches for the four topics (see 2.1) yielded a total of $18^{\prime} 235$ hits after removing duplicates. After screening of titles and abstracts for these four topics, 387 articles remained. Reviewing the fulltext articles with respect to the topic of MHT and dementia, 54 relevant articles were identified which were included in this paper (supplementary file 2). 
Table 1

Original articles on the impact of MHT on dementia risk published between September 2019 and February 2021.

\begin{tabular}{|c|c|c|c|c|c|c|c|c|}
\hline $\begin{array}{l}\text { Author, } \\
\text { year of } \\
\text { publication }\end{array}$ & $\begin{array}{l}\text { Study } \\
\text { design }\end{array}$ & $\begin{array}{l}\text { Sample } \\
\text { size }\end{array}$ & $\begin{array}{l}\text { Cohort's } \\
\text { characteristics }\end{array}$ & Intervention & $\begin{array}{l}\text { Follow- } \\
\text { up }\end{array}$ & Endpoint(s) & $\begin{array}{l}\text { Method for } \\
\text { endpoint(s) } \\
\text { assessment }\end{array}$ & Results \\
\hline $\begin{array}{c}\text { Yoo, } 2020 \\
{[1]}\end{array}$ & $\begin{array}{l}\text { Prospective } \\
\text { cohort } \\
\text { study }\end{array}$ & $4^{\prime} 696^{\prime} 633$ & $\begin{array}{l}\text { Postmenopausal } \\
\text { non- } \\
\text { hysterectomized } \\
\text { women from the } \\
\text { Korean National } \\
\text { Health Insurance } \\
\text { System database; } \\
\text { mean age } 61.2 \text { yrs } \\
\text { (SD } 8.6 \text { yrs); BMI: } \\
<18.5 \text { ( } 2.3 \%), \\
18.5-23(35.6 \%), \\
23-25(26.1 \%), 25 \\
-30(31.5 \%), \geq 30 \\
(4.5 \%) ; \text { mean age } \\
\text { at menopause: } \\
50.2 \text { yrs (SD } \\
4.0 \text { yrs); MHT } \\
\text { duration: never } \\
\text { ( } 81.6 \%),<2 \text { yrs } \\
\text { (8.7\%), } 2-5 \text { yrs } \\
(3.4 \%), \geq 5 \text { yrs } \\
\text { (3.7\%), unknown } \\
\text { (3.7\%) }\end{array}$ & MHT & $\begin{array}{l}\text { Median } \\
5.74 \text { yrs. }\end{array}$ & $\begin{array}{l}\text { Incident } \\
\text { dementia } \\
\text { (AD, VaD, } \\
\text { other) }\end{array}$ & $\begin{array}{l}\text { Self- } \\
\text { administered } \\
\text { questionnaire, } \\
\text { ICD codes for } \\
\text { dementia, anti- } \\
\text { dementia drug } \\
\text { prescription } \\
\text { database; } \\
\text { multivariate- } \\
\text { adjusted } \\
\text { proportional } \\
\text { hazards model } \\
\text { (age at } \\
\text { menarche, age } \\
\text { at menopause, } \\
\text { parity, duration } \\
\text { of } \\
\text { breastfeeding, } \\
\text { duration of } \\
\text { MHT, duration } \\
\text { of OC use, } \\
\text { alcohol } \\
\text { consumption, } \\
\text { smoking, } \\
\text { regular } \\
\text { exercise, } \\
\text { income, BMI, } \\
\text { hypertension, } \\
\text { diabetes } \\
\text { mellitus, } \\
\text { dyslipidemia, } \\
\text { cancer) }\end{array}$ & $\begin{array}{l}212^{\prime} 227 \\
\text { incident } \\
\text { cases of } \\
\text { dementia, } \\
\text { incidence } \\
\text { rate (per } \\
1000 \text { person- } \\
\text { yrs.: } 8.6 \text { ); } \\
\text { never MHT } \\
\text { vs. 1) all MHT } \\
\text { user: } \\
\text { HR 0.85 (no } \\
\text { 95\% CI } \\
\text { provided), 2) } \\
\text { MHT <2 yrs: } \\
\text { HR 0.86 (95\% } \\
\text { CI 0.84 } \\
-0.88), 3 \text { ) } \\
\text { MHT 2-5 yrs: } \\
\text { HR 0.81 (95\% } \\
\text { CI 0.78 } \\
-0.84), 4) \\
\text { MHT } \geq 5 \text { yrs: } \\
\text { HR 0.87 (95\% } \\
\text { CI 0.84-0.90) }\end{array}$ \\
\hline $\begin{array}{c}\text { Han, } 2020 \\
{[2]}\end{array}$ & $\begin{array}{l}\text { Prospective } \\
\text { cohort } \\
\text { study }\end{array}$ & $13^{\prime} 110$ & $\begin{array}{l}\text { Postmenopausal } \\
\text { women from the } \\
\text { Korean National } \\
\text { Health Insurance } \\
\text { System database; } \\
\text { no prior tibolone } \\
\text { use, mean age of } \\
\text { user } 58.2 \text { yrs (SD } \\
6.2 \text { yrs) and of } \\
\text { nonuser } 61.8 \text { yrs } \\
\text { (SD 7.9), mean } \\
\text { BMI of (non)user } \\
24.2\end{array}$ & Tibolone & $\begin{array}{l}\text { Total } \\
9 \text { yrs. }\end{array}$ & $\begin{array}{l}\text { Incident } \\
\text { dementia } \\
\text { (total, AD, } \\
\text { VaD, }\end{array}$ & $\begin{array}{l}\text { ICD codes for } \\
\text { dementia, anti- } \\
\text { dementia drug } \\
\text { and tibolone } \\
\text { prescription } \\
\text { database; } \\
\text { multivariate- } \\
\text { adjusted } \\
\text { proportional } \\
\text { hazards model } \\
\text { (age, BMI, } \\
\text { smoking, } \\
\text { alcohol } \\
\text { consumption, } \\
\text { physical } \\
\text { activity, systolic } \\
\text { blood pressure, } \\
\text { fasting blood } \\
\text { glucose, total } \\
\text { cholesterol } \\
\text { Charlson } \\
\text { comorbidity } \\
\text { index, } \\
\text { comedication, } \\
\text { socioeconomic } \\
\text { status }\end{array}$ & $\begin{array}{l}940 \text { incident } \\
\text { cases of } \\
\text { dementia } \\
\text { ( } 883 \mathrm{AD}, 206 \\
\text { VaD); } \\
\text { Tibolone use } \\
\text { vs. nonuse: } 1 \text { ) } \\
\text { total } \\
\text { dementia: HR } \\
1.04 \text { (95\% CI } \\
0.73-1.47) \text {, } \\
\text { 2) AD: HR } \\
0.95 \text { (95\% CI } \\
0.65-1.38) \text {, } \\
\text { 3) VaD: HR } \\
\text { 1.25 (95\% CI } \\
0.63-2.46) ; \\
\text { cumulative } \\
\text { dose, } \\
\text { treatment } \\
\text { duration and } \\
\text { age at } \\
\text { initiation did } \\
\text { not have a } \\
\text { significant } \\
\text { impact }\end{array}$ \\
\hline
\end{tabular}


Table 1 (continued)

\begin{tabular}{|c|c|c|c|c|c|c|c|c|}
\hline $\begin{array}{l}\text { Author, } \\
\text { year of } \\
\text { publication }\end{array}$ & $\begin{array}{l}\text { Study } \\
\text { design }\end{array}$ & $\begin{array}{l}\text { Sample } \\
\text { size }\end{array}$ & $\begin{array}{l}\text { Cohort's } \\
\text { characteristics }\end{array}$ & Intervention & $\begin{array}{l}\text { Follow- } \\
\text { up }\end{array}$ & Endpoint(s) & $\begin{array}{l}\text { Method for } \\
\text { endpoint(s) } \\
\text { assessment }\end{array}$ & Results \\
\hline $\begin{array}{l}\text { Paganini- } \\
\text { Hill, } 2020 \\
\text { [3] }\end{array}$ & $\begin{array}{l}\text { Prospective } \\
\text { cohort } \\
\text { study }\end{array}$ & 424 & $\begin{array}{l}\text { Postmenopausal } \\
\text { women without } \\
\text { dementia at } \\
\text { baseline, mean } \\
\text { age } 68.5 \text { yrs (SD } \\
5.0 \text { ) at enrollment } \\
\text { in Leisure World } \\
\text { Cohort study } \\
\text { (when } \\
\text { information on } \\
\text { reproductive } \\
\text { parameters were } \\
\text { assessed by } \\
\text { questionnaire), } \\
\text { mean age 93.2 yrs } \\
\text { (SD 2.6) at } \\
\text { enrollment in The } \\
\text { 90+ Study (when } \\
\text { cognitive } \\
\text { function was } \\
\text { assessed } \\
\text { prospectively) }\end{array}$ & MHT & $\begin{array}{l}\text { Mean } \\
3.4 \text { yrs } \\
\text { (SD 2.5) }\end{array}$ & $\begin{array}{l}\text { Incident } \\
\text { dementia }\end{array}$ & $\begin{array}{l}\text { Questionnaire } \\
\text { on } \\
\text { reproductive } \\
\text { factors (part of } \\
\text { the Leisure } \\
\text { World Cohort } \\
\text { study), } \\
\text { neurological } \\
\text { examination, } \\
\text { MMSE (if face- } \\
\text { to-face } \\
\text { consultation } \\
\text { was possible), } \\
\text { CASI-short } \\
\text { (telephone } \\
\text { interview with } \\
\text { subject if face- } \\
\text { to-face } \\
\text { consultation } \\
\text { was } \\
\text { impossible), DQ } \\
\text { (telephone } \\
\text { interview with } \\
\text { informant (if } \\
\text { neither face-to- } \\
\text { face nor } \\
\text { telephone } \\
\text { interview with } \\
\text { subject was } \\
\text { possible) }\end{array}$ & $\begin{array}{l}209 \text { incident } \\
\text { cases of } \\
\text { dementia, } \\
\text { never vs. ever } \\
\text { MHT: } \\
\text { adjusted HR } \\
0.94 \text { (95\% CI } \\
0.69-1.28) \text {, } \\
\text { neither dose, } \\
\text { duration nor } \\
\text { time since } \\
\text { last use was } \\
\text { associated } \\
\text { with } \\
\text { dementia risk } \\
\text { after age } \\
90 \text { yrs. }\end{array}$ \\
\hline
\end{tabular}

Abbreviations: $\mathrm{AD}=$ Alzheimer's disease, $\mathrm{BMI}=$ Body Mass Index, CASI = Cognitive Abilities Screening Instrument, $\mathrm{CI}=\mathrm{Con}$ fidence Interval, DQ = Dementia Questionnaire, HR = Hazard Ratio, MHT = Menopausal Hormone Therapy, MMSE $=$ MiniMental State Examination, $\mathrm{SD}=$ Standard Deviation, $\mathrm{VaD}=$ Vascular Dementia, yrs. = years.

\section{Results}

Impact of MHT on dementia and Alzheimer's disease risk

Our systematic literature search identified four systematic reviews and meta-analyses [8-11], of which two were published in 2020 [8,10] including original articles published until June 2019 [10] and September 2019 [8], respectively. According to our systematic literature search three additional original articles have been published since then [12-14] (Table 1).

The first meta-analysis [8] included 18 studies of which 13 focused on AD [15-28] and five on not further specified dementia [20,29-32]. The second meta-analysis [10] included 16 studies focusing on AD [18,19,21-24,26,28,33-40]. Thus, only eight original studies were included in both meta-analyses. Furthermore, our systematic literature search identified five additional original articles not having been included in any of the two meta-analyses [41-45] (supplementary table 1 and table 2).

The first meta-analysis [8] reported a significantly increased risk for AD (OR 1.08, 95\% CI 1.03-1.14) and overall dementia (OR 1.16, 95\% CI 1.02-1.31) in MHT users compared to hormone-naïve women. However, this association was not found when only including cohort studies (AD: OR 0.89, 95\% CI 0.76-1.04; dementia OR 1.13, 95\% CI 0.97-1.33) [17,18,20,24,26,31,32,46]. The two articles from the RCT WHI reporting an increased dementia risk for MHT user only focused on women above age 65 when initiating MHT [29,30] thus not considering the hypothesized neuroprotective "critical window" [32]. However, overall, meta-regression based on baseline age of subjects did not reveal this parameter as a 
source of heterogeneity for AD or dementia diagnosis, respectively. When considering type of MHT specifically combined MHT (mainly estrogens combined with the synthetic progestogen MPA) displayed a negative impact (OR $1.16,95 \%$ CI $1.12-1.21$ ) while progestogen only and estrogen only therapy only had a minor effect. Interestingly, the observed significant positive correlation between MHT and $\mathrm{AD}$ was only found for women using MHT for up to five years (Coef $=0.0477, \mathrm{p}<0.001$ ). When MHT was used for more than five years $A D$ risk significantly declined (Coef $=-0.0932, p<0.001$ ). Accordingly, longer MHT duration displayed a protective effect on AD. The second meta-analysis [10] reported a significantly decreased risk for AD in MHT user (OR 0.672, 95\% CI 0.581-0.779; p < 0.001) which was not significantly modified by, e.g. age (age $\leq 70$, age $71-79$, age $\geq 80$ ), MHT ascertainment (oral, transdermal estrogens) and treatment duration ( $<5$ years, $5-10$ years, $>10$ years). Comparable to the first meta-analysis [8], when only prospective cohort studies were included, the effect size was increased supporting the beneficial effect of MHT in cognition (OR 0.519, 95\% CI 0.413-0.653; $\mathrm{p}<0.001$ ). However, the meta-analysis did not differentiate between estrogen only and combined EPT.

Table 2 presents the additional five original articles identified by our systematic literature search [41-45]. Two articles were derived from the placebo-controlled randomized Women's Health Initiative Memory Study (WHIMS) [43,44] while the others either were cross-sectional [41], retrospective [42]) cohort, or case-control [45] studies. Sample size ranged from 30 [41] to 489,105 [42] women. MHT either comprised oral estrogens (CEE [43], E2 [42]) combined with a progestin (MPA only [43], mainly MPA or norethisterone acetate (NETA) [42]), estrogens only (CEE) [44], or was not further specified [41,45], respectively. Mean MHT duration ranged from four [43] to 6.8 [42] years, or was not reported $[41,45]$. In those studies providing details on MHT type and duration, risk of incident dementia (mainly AD) was either significantly increased by EPT in women initiating MHT at age 65+ [43] or unaffected by estrogen only therapy (ET) [44]. On the contrary, risk of death due to AD or vascular dementia was significantly reduced by MHT regardless of age at MHT initiation [42].

All three original studies published in 2020 (Table 1) were prospective cohort studies performed in South Korea [12,14] or USA [13], respectively. Sample size ranged from 424 [13] to more than 4.5 million [14] postmenopausal women. At baseline, mean age of South Korean women was approximately 58-63 years [12,14] while US-American women had a mean age of 93 years [13]. Mean follow-up was 3.4 [13] to nine years [12]. In all studies, incident dementia was the primary endpoint. Dementia cases were either identified by ICD codes in the National Health Insurance System database [12,14], and by neurological examination or telephone interviews [13], respectively. For dementia risk analysis, women using MHT were compared to MHT nonuser adjusting for several potential confounding factors. MHT was only specified in one study (tibolone) [12] while MHT type, mode of application and dosage were not reported in the remainder $[13,14]$. However, as the largest study only included nonhysterectomized women it can be assumed that only combined MHT was applied [14]. It was also this study [14] that reported a significant reduction of overall dementia (including AD and vascular dementia) by MHT regardless of MHT duration. The remainder did not report a significant impact of MHT on overall dementia risk. Similarly, MHT duration [12,13] and age at initiation [12] did not alter their results.

\section{Cognitive "window of opportunity" hypothesis}

The "window of opportunity" hypothesis proposes that following long-term ovarian hormone deprivation, the brain and cognition become insensitive to exogenously administered estrogens, while in contrast, if estrogens are administered during a critical period near menopause, they will exert beneficial effects [47]. Accordingly, some observational cohort studies, reviewed in 2014 [48], suggested that MHT use in the early postmenopausal years was associated with a lower risk of dementia, while later MHT use was not. In detail, the large Multi-Institutional Research on Alzheimer Genetic Epidemiology (MIRAGE) case-control study reported a reduced AD risk only in younger postmenopausal MHT user [39]. In the Kaiser Permanente integrated health care system, self-reported MHT use at midlife but not nearly 30 years later, was associated with a significant reduction in risk of allcause dementia [31]. In the Cache County cohort study of healthy postmenopausal women age 65 years and older, self-reported initiation of MHT within five years of menopause was linked to a significant reduction in incident AD, whereas later initiation did not alter risk [19]. These observations 
Table 2

Additional original articles on the impact of MHT on dementia risk identified by our systematic literature search.

\begin{tabular}{|c|c|c|c|c|c|c|c|c|}
\hline $\begin{array}{l}\text { Author, } \\
\text { year of } \\
\text { publication }\end{array}$ & $\begin{array}{l}\text { Study } \\
\text { design }\end{array}$ & $\begin{array}{l}\text { Sample } \\
\text { size }\end{array}$ & Cohort's characteristics & Intervention & Follow-up & Endpoint(s) & $\begin{array}{l}\text { Method for endpoint(s) } \\
\text { assessment }\end{array}$ & Results (selection) \\
\hline $\begin{array}{l}\text { Levine \& } \\
\text { Hewett, } \\
2003 \text { [1] }\end{array}$ & Cohort & 30 & $\begin{array}{l}\text { Postmenopausal women } \\
\text { with FTD, mean age at } \\
\text { evaluation } 70 \text { yrs (range } 51 \\
\text { - } 91 \text { yrs); mean age of } \\
\text { dementia onset } 64.9 \text { yrs } \\
\text { (range } 46-87 \text { yrs) }\end{array}$ & $\begin{array}{l}\text { MHT (not further } \\
\text { specified) }\end{array}$ & $\begin{array}{l}\text { Assessment only } \\
\text { once (cross- } \\
\text { sectional) }\end{array}$ & $\begin{array}{l}\text { Prevalence of MHT } \\
\text { use in FTD women } \\
\text { compared to the } \\
\text { general population } \\
\text { (national estimate } \\
24 \% \text { ) }\end{array}$ & Chi-square analysis & $\begin{array}{l}\text { Prevalence of MHT } \\
\text { use was } \\
\text { significantly higher } \\
\text { in FTD women } \\
\text { compared to the } \\
\text { general population } \\
(p<0.01) \text {. }\end{array}$ \\
\hline $\begin{array}{l}\text { Mikkola, } \\
2017 \text { [2] }\end{array}$ & Cohort & $489 ’ 105$ & $\begin{array}{l}\text { Postmenopausal women } \\
\text { with MHT mean duration } \\
6.8 \text { yrs (SD 6.0); death due } \\
\text { to AD } n=1057 \text { resp. VaD } \\
n=581 \text {; prevalence of } \\
\text { myocardial infarction } \\
\text { preceding MHT initiation } \\
\text { was higher in MHT user } \\
(2.3 \%) \text { than in reference } \\
\text { population }(1.4 \%)\end{array}$ & $\begin{array}{l}\text { ET and EPT; 90\% oral } \\
\text { MHT; estrogen type } \\
\text { only E2, progestogen } \\
\text { type mostly MPA and } \\
\text { NETA }\end{array}$ & $\begin{array}{l}\text { Observation period } \\
\text { for deaths } 1998 \\
-2009\end{array}$ & $\begin{array}{l}\text { Standardized } \\
\text { Mortality ratio } \\
\text { (SMR) for AD and } \\
\text { VaD }\end{array}$ & $\begin{array}{l}\text { The number of deaths } \\
\text { as a result of VaD and } \\
\mathrm{AD} \text { in MHT users were } \\
\text { compared with those } \\
\text { that occurred in the } \\
\text { age-standardized } \\
\text { Finnish female } \\
\text { Population at 5-yr } \\
\text { intervals (expected } \\
\text { deaths); data source of } \\
\text { women who died from } \\
\text { AD and VaD: } \\
\text { nationwide } \\
\text { prescription register, } \\
\text { National Cause-of- } \\
\text { Death Register, } \\
\text { National Hospital } \\
\text { Discharge Register }\end{array}$ & $\begin{array}{l}\text { VaD death risk was } \\
\text { significantly } \\
\text { reduced by MHT } \\
\text { regardless of MHT } \\
\text { type and duration } \\
\text { ( }>0 \text { to } \leq 5 \text { yrs. SMR } \\
0.63,95 \% \text { CI } 0.55 \\
-0.72 ;>5 \text { yrs. SMR } \\
0.61,95 \% \text { CI } 0.54 \\
-0.67 \text { ); } \\
\text { AD death risk was } \\
\text { significantly } \\
\text { reduced by any } \\
\text { MHT if MHT } \\
\text { duration was } \\
>5 \text { yrs, (SMR } 0.85 \text {, } \\
95 \% \text { CI } 0.79-0.92 \text { ); } \\
\text { AD and VaD death } \\
\text { risk reduction by } \\
\text { MHT was not } \\
\text { affected by age at } \\
\text { MHT initiation. }\end{array}$ \\
\hline $\begin{array}{l}\text { Shumaker, } \\
2003[3]\end{array}$ & PC-RCT & 4532 & $\begin{array}{l}\text { Postmenopausal women } \\
\text { with a uterus, participants } \\
\text { in WHI with age } \geq 65 \text { yrs } \\
\text { and no dementia at } \\
\text { enrollment; } 1-2 \% \text { with } \\
\text { history of stroke }\end{array}$ & $\begin{array}{l}\text { oCEE } 0.625 \mathrm{mg} / \text { day } \\
\text { combined with MPA } \\
2.5 \mathrm{mg} / \mathrm{day}(\mathrm{n}=2229) \text {, } \\
\text { placebo }(\mathrm{n}=2303)\end{array}$ & $\begin{array}{l}\text { EPT mean } 4.01 \text { yrs } \\
\text { (SD 1.21), placebo } \\
\text { mean } 4.06 \text { yrs (SD } \\
1.18)\end{array}$ & $\begin{array}{l}\text { All-cause dementia, } \\
\text { mild cognitive } \\
\text { impairment, global } \\
\text { cognitive } \\
\text { functioning }\end{array}$ & $\begin{array}{l}\text { Phase } 1: 3 \mathrm{MSE} \text { at } \\
\text { baseline and annually } \\
\text { Phase } 2 \text { : if } 3 \mathrm{MSE} \text { score } \\
\text { was below defined cut } \\
\text { points }>\text { modified } \\
\text { CERAD } \\
\text { neuropsychological } \\
\text { battery, standardized }\end{array}$ & $\begin{array}{l}\text { During Follow-up } \\
61 \text { cases of } \\
\text { dementia were } \\
\text { identified (EPT } \\
\mathrm{n}=40 \text {, placebo } \\
\mathrm{n}=21): \text { HR } 2.05 \\
(95 \% \text { CI } 1.21-3.48) ; \\
\text { dementia type: }\end{array}$ \\
\hline
\end{tabular}


Phase 3: results from

phase $1+2$ were

reviewed by clinician

and diagnosis was

made (no dementia/

$\mathrm{MCI} /$ dementia)

Phase 4: if dementia

was diagnosed $>$ brain

computed tomography

scan, blood sampling

Shumaker, PC-RCT 2004 [4]
2947
Postmenopausal women $\quad$ oCEE $0.625 \mathrm{mg} / \mathrm{day}$ without uterus, participants $(\mathrm{n}=1464)$, placebo in WHI with age $\geq 65$ yrs $\quad(n=1483)$

and no dementia at

enrollment; $1.8-2.1 \%$ with

history of stroke
ET mean 5.16 yrs

(SD 1.77), placebo

mean 5.20 yrs (SD

1.71

All-cause dementia, Phase 1: 3MSE at

mild cognitive

baseline and annually

impairment, global

cognitive

functioning was below defined
points $>$ modified
Phase 2: if 3MSE score

CERAD

neuropsychological

battery, standardized

interview by certified

technician,

standardized

questionnaire (patient,

informant)

Phase 3: results from

reviewed by clinician

and diagnosis was

made (no dementia/

$\mathrm{MCl} /$ dementia)

Phase 4: if dementia

was diagnosed $>$ brain

computed tomography

scan, blood sampling
During Follow-up

$$
7 \text { cases of }
$$

dementia were

identified (ET

$n=28$, placebo
$n=19):$ HR 1.49

(95\% CI 0.83-2.66);

dementia type:

mostly AD (ET

46.4\%, placebo

47.4.1\%); ET

without impact on

$\mathrm{MCl}$ risk; HR for

dementia in pooled

trials (ET + EPT)

2.19 (95\% CI 1.25

$-3.84, \mathrm{p}=0.006)$

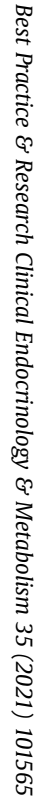


Zucchella, Case-control AD 2012 [5]

\section{patients}

$\mathrm{n}=275$,

controls

$\mathrm{n}=276$
Postmenopausal women,

mean age 76.7-77.6 yrs,

mean $\mathrm{AD}$ duration in $\mathrm{AD}$

patients 2.9 yrs (SD1.6)
MHT (not further

specified)

Assessment only
once (cross-
sectional)

sectional)
Cases and controls Cases and controls

- Personal history - Structured interview

including major • MMSE

reproductive life Cases only

events and exog- - ADL

enous sex hor- • ISDL

mone exposure - NPI

- Global cognitive • CDR

evaluation

Cases only

- Basic everyda

activities

- More complex

everyday

activities

- Behavioral

disturbances

- Dementia

severity
Abbreviations: $\mathrm{AD}=$ Alzheimer's disease, $\mathrm{ADL}=$ Activities of Daily Living, $\mathrm{CDR}=$ Clinical Dementia Rating, $\mathrm{CEE}=$ conjugated equine estrogens, CERAD = Consortium to Establish a Registry
for $\mathrm{AD}, \mathrm{CI}=$ Confidence Interval, $\mathrm{ET}=$ estrogen therapy, $\mathrm{EPT}=$ estrogen progestogen therapy, $\mathrm{FTD}=$ frontotemporal dementia, $\mathrm{HR}=\mathrm{Hazard}$ Ratio, IADL $=\mathrm{Instrumental} \mathrm{Activities}$ of Daily

6 Living, $\mathrm{MCI}=$ mild cognitive impairment, MHT = Menopausal Hormone Therapy, (3)MMSE = (modified) Mini-Mental State Examination, MPA = medroxyprogesterone acetate, $\mathrm{NETA}=$ norethisterone acetate, $\mathrm{NPI}=$ Neuropsychiatric Inventory, $\mathrm{o}=$ oral, $\mathrm{PC}-\mathrm{RCT}=$ placebo-controlled randomized trial, $\mathrm{SD}=\mathrm{Standard}$ Deviation, $\mathrm{VaD}=\mathrm{Vascular}$ Dementia, $\mathrm{WHI}=$ Women's Health Initiative, yrs. = years. 
seem to be supported by the Kronos Early Estrogen Prevention Study (KEEPS) trial showing that transdermal E2 therapy was associated with a decrease in amyloid-beta deposition on neuroimaging studies, particularly in apolipoprotein E (APOE) E4 carriers [49], and by the WHIMS reporting an increased risk of dementia in women older than 65 years when initiating EPT (no younger cohort to compare with) [43].

However, the critical timing hypothesis was not supported by the two most recent meta-analyses showing no impact of age at MHT initiation and MHT duration [8,10]. Similarly, the three studies published in 2020, did not find an impact of MHT duration [12-14] and age at initiation [12] on incident dementia risk. Furthermore, the large Finnish cohort study did not find an age-modifying effect on risk reduction for death due to AD or vascular dementia by MHT [42].

\section{Impact of MHT in women with Alzheimer's disease and dementia}

Our systematic literature search identified 14 original articles [50-63] (Table 3) and one metaanalysis [64] on the impact of MHT on cognitive function in postmenopausal women with dementia. While case-control [54], cross-sectional [55,58,62], and prospective cohort studies [52,53,60] mostly reported a beneficial effect of estrogens on cognitive function in $A D$ females, the meta-analysis comprising of RCTs only did not [64]. The latter argued that due to different MHT regimens applied and study designs chosen it was not possible to combine more than two studies in any analysis. Accordingly, the authors concluded that MHT was not indicated for cognitive improvement or maintenance for women with $\mathrm{AD}$.

\section{Counseling tool for daily practice}

Healthy ageing includes survival to old age, delay in the onset of NCD and optimal functioning for a maximal period at individual levels of body systems and cells. In 2016, EMAS published

The conceptual framework of Healthy Menopause, a holistic model of care covering physical, psychological and social functioning and incorporating disease and disability. It encompasses women as a whole, beyond their hormonal, reproductive and physiological health [65]. Accordingly, cognitive aging and dementia prevention should be part of counselling in midlife women. Apart from age, there are several hereditary (disposition) and acquired (exposition) risk factors for developing dementia and AD, respectively. Hereditary AD risk factors comprise a family history of dementia, rare dominantly inherited mutations in genes that impact amyloid in the brain, and the APOE epsilon 4 allele. A recent meta-umbrella systematic review of umbrella reviews put together risk and protective factors of noncommunicable neurological disorders including (vascular) dementia and AD [66]. The most prominent risk factors were T2DM, high midlife BMI, hypertension, smoking, low-frequency electromagnetic fields, mild traumatic brain injury, depression, low level of education and frequency of social contacts, respectively (Table 4). The most prominent protective factors were lifestyle (Mediterranean diet, high fish intake, coffee consumption, light or moderate alcohol intake, high physical activity, micronutrients (vitamin C and E), some drugs (e.g., statins, antihypertensive drugs, aspirin, NSAIDS), and personality (e.g. openness) (Table 5). In this meta-umbrella systematic review, MHT is neither mentioned as risk nor as protective factor for developing dementia and $A D$, respectively. However, this may be due to not differentiating risk/protective factors for sex. According to our and other previous systematic literature searches and meta-analyses, MHT is not indicated in already demented women for cognitive improvement (section Impact of MHT in women with Alzheimer's disease and dementia). However, MHT may be a protective factor for developing AD in (healthy) menopausal women (section Impact of MHT on dementia and Alzheimer's disease risk). In fact, the RCT WHIMS only including MHT starters at age 65+ has been the only study so far, showing a negative impact of combined EPT on dementia risk [43]. However, this may also be due to the participants' higher age, other prevalent risk factors, or the applied EPT containing MPA. MPA exerts glucocorticoid effects supporting fluid retention and thus blood pressure increase, causes an impairment of glucose tolerance, and stimulates the procoagulatory activity in the vessel wall [67], all of which may have a detrimental effect on the brain. In contrast, many studies have been published demonstrating a direct beneficial effect of estrogens on brain tissue [68]. Furthermore, estrogens display a beneficial impact on most risk and protective factors 
Table 3

Original articles on the impact of MHT in women with dementia.

\begin{tabular}{|c|c|c|c|c|c|c|c|c|}
\hline $\begin{array}{l}\text { Author, year of } \\
\text { publication }\end{array}$ & $\begin{array}{l}\text { Study } \\
\text { design }\end{array}$ & Sample size & $\begin{array}{l}\text { Cohort's } \\
\text { characteristics }\end{array}$ & Intervention & $\begin{array}{l}\text { Intervention (post- } \\
\text { intervention Follow-up) }\end{array}$ & Endpoint(a) & $\begin{array}{l}\text { Method for endpoint(s) } \\
\text { assessment }\end{array}$ & Results (selection) \\
\hline $\begin{array}{l}\text { Asthana, } 1999 \\
\text { [1] }\end{array}$ & $\begin{array}{l}\text { Pilot PC- } \\
\text { RCT }\end{array}$ & 12 & $\begin{array}{l}\text { AD women without } \\
\text { other significant } \\
\text { medical, } \\
\text { neurological or } \\
\text { psychiatric diseases; } \\
\text { no MHT or } \\
\text { psychoactive } \\
\text { medication during } \\
\text { past } 2 \text { months; } \\
\text { mean age } 79.5 \text { (SD } \\
\text { 7.7.9) and } 77.6 \text { (SD } \\
\text { 6.6) yrs. }\end{array}$ & $\begin{array}{l}\text { tE2 } 50 \mathrm{mcg} / \text { day, } \\
\text { placebo }\end{array}$ & 8 wks (5 wks) & $\begin{array}{l}\text { - Cognitive do- } \\
\text { mains memory, } \\
\text { attention and } \\
\text { language } \\
\text { - Dementia } \\
\text { severity } \\
\text { - Mood } \\
\text { - Serum estrogens, } \\
\text { catecholamines, } \\
\text { IGF system }\end{array}$ & $\begin{array}{l}\text { - Neuropsychological test } \\
\text { battery at baseline and } \\
\text { wk } 1,3,5,8,9,10,11,13 \text { : } \\
\text { 1) memory (Buschke Se- } \\
\text { lective Reminding Test, } \\
\text { Paragraph Recall Test, } \\
\text { Visual Reproduction } \\
\text { Test), 2) attention (Stroop } \\
\text { Color Word Interference } \\
\text { Test, Trail-Making Test), } \\
\text { 3) language (Verbal } \\
\text { Fluency Test, Token } \\
\text { Test); } \\
\text { - MMSE, BMICT } \\
\text { - BPRS } \\
\text { - Blood sample }\end{array}$ & $\begin{array}{l}\text { E2 improved verbal } \\
\text { memory (significant) } \\
\text { and visual memory } \\
\text { (borderline significant), } \\
\text { E2 significantly } \\
\text { improved attention. } \\
\text { After treatment } \\
\text { discontinuation the E2 } \\
\text { effect vanished. } \\
\text { E2 without effect on } \\
\text { other } \\
\text { neuropsychological } \\
\text { tests. }\end{array}$ \\
\hline $\begin{array}{l}\text { Asthana, } 2001 \\
\text { [2] }\end{array}$ & PC-RCT & 20 & $\begin{array}{l}\text { AD women without } \\
\text { other significant } \\
\text { medical, } \\
\text { neurological or } \\
\text { psychiatric diseases; } \\
\text { no MHT or } \\
\text { psychoactive } \\
\text { medication during } \\
\text { past } 2 \text { months; } \\
\text { mean age } 79.0 \text { (SD } \\
\text { 9.7) and } 80.2 \text { (SD } \\
\text { 6.7) yrs., } n=8 \text { with } \\
\text { hysterectomy }\end{array}$ & $\begin{array}{l}\text { tE2 } 100 \mathrm{mcg} / \text { day, } \\
\text { placebo }\end{array}$ & 8 wks ( 8 wks) & $\begin{array}{l}\text { - Cognitive do- } \\
\text { mains attention } \\
\text { and memory } \\
\text { - Dementia } \\
\text { severity } \\
\text { - Mood } \\
\text { - Relative change } \\
\text { in subject's } \\
\text { global cognitive } \\
\text { and behavioral } \\
\text { status } \\
\text { (physician) } \\
\text { - Physical function } \\
\text { - Serum estrogens, } \\
\text { catecholamines, } \\
\text { IGF system }\end{array}$ & $\begin{array}{l}\text { - Neuropsychological test } \\
\text { battery at baseline and } \\
\text { wk 3,5, } 8 \text { and 16: 1) } \\
\text { attention (Stroop Color } \\
\text { Word Interference Test, } \\
\text { Trail-Making Test, } \\
\text { Treisman Visual Search), } \\
\text { 2) recent verbal memory } \\
\text { (Buschke Selective } \\
\text { Reminding Test, Story } \\
\text { Recall), 3) Recent visual } \\
\text { memory (Figure Copy/ } \\
\text { Memory, Visual Paired- } \\
\text { Associates, Oculomotor } \\
\text { Delayed Response), 4) } \\
\text { semantic memory } \\
\text { (Boston Naming Test); } \\
\text { - MMSE, BMICT } \\
\text { - BPRS } \\
\text { - CIBIC } \\
\text { - IADL, PSMS } \\
\text { - Blood sample }\end{array}$ & $\begin{array}{l}\text { E2 significantly } \\
\text { improved attention } \\
\text { (Stroop Color Word } \\
\text { Interference Test) } \\
(\mathrm{p}=0.02) \text {, verbal } \\
\text { memory (Buschke } \\
\text { Selective Reminding } \\
\text { Test) }(\mathrm{p}=0.049) \text { and } \\
\text { visual memory } \\
\text { (Figure Copy/Memory) } \\
\text { (p=0.02); E2 without } \\
\text { effect on other } \\
\text { neuropsychological } \\
\text { tests }\end{array}$ \\
\hline
\end{tabular}


Intervention

Intervention (post-

Endpoint(a)

Method for endpoint(s)

Results (selection)

publication

characteristics

intervention Follow-up)

assessment

$\begin{array}{llll}\text { Fillit, 1986 [4] Cohort } & 7 & \begin{array}{l}\text { AD women without oE2 } 2 \mathrm{mg} / \text { day } \\ \text { other significant } \\ \text { medical diseases }\end{array}\end{array}$

Not

medical diseases

Fillit, 1994 [5] Case report

$\begin{array}{cll}\text { Henderson, } & \text { Case- } & 235(\mathrm{AD} \\ 1994[6] & \text { control } & \mathrm{n}=143 \\ & & \text { controls } \\ & & \mathrm{n}=92)\end{array}$

78 yr old

with $\mathrm{AD}$

Age of AD women $\quad \mathrm{ET}$ in $10(7 \%) \mathrm{AD}$

76.0 yrs (SD 8.9) and cases and in 17

of controls 76.3 (SD (18\%) controls;

8.5) yrs.; no

significant

intergroup

difference for

education and

symptom duration

Henderson, Cohort

63

1996 [7]

AD women with

$\operatorname{MHT}(\mathrm{n}=9)$, AD

MHT $(n=27)$, AD

oCEE $0.3-1.25 \mathrm{mg} /$

day $(\mathrm{n}=8), \mathrm{E} 1$

$0.625 \mathrm{mg} /$ day

age $74.3-75.3$ yrs. $\quad(n=3)$

6 wks (3 wks)

4 wks (3 wks) $\quad \begin{aligned} & \text { Not further } \\ & \text { specified }\end{aligned}$

Assessment only once (cross-sectional)

Global dementia severity
Neuropsychological test

in $4 \mathrm{AD}$ women were responders defined as

battery:

- Global deterioration improvement of MMSE

Scale Ham-D and Randt

- Blessed Dementia Scale Memory test;

- Ham-D

responders were older

- Wechsler Adult Intelli- at AD onset und had less

gence Scale severe dementia at

- MMSE baseline

- Hachinski Ischemic Score

- Randt Memory Test

- Mattis Dementia Rating

Scale

- MMSE

- Paired

E2 improved MMSE and

learning learning with only little

- Bradburn Affect Balance change of mood.

Scale

MMSE

AD cases with ET

performed significantly

better than $\mathrm{AD}$ controls $(\mathrm{p}=0.02)$

Assessment only once

- global dementia Neuropsychological test

severity

battery:

- semantic

- MMSE, OMC

AD women with MHT

scored significantly

memory

- BNT, fluen

better than women

semantic without MHT on

tasks - Fluency: FAS, compre- (BNT), verbal short-term

- visuospatial

memory

hension: Token Test

memory (DSF, DSB),

- verbal episodic ings, CERAD drawings (clock and house

- verbal short- $\bullet$ DSF, DSB

term memory - VMSF, VMSB

significant trend for $\mathrm{AD}$

women with MHT to

- GDS

wom with 
- nonverbal short-

term memory

- depression

retrieval task and

language

comprehension (Token

Test); no significant

difference between $A D$

women with $\mathrm{MHT}$

compared to $\mathrm{AD}$ men;

no significant

intergroup difference

for depression

- No significant group differences for ADAS-

$\begin{array}{llll}\text { - Global change } & \text { - ADL/IADL } & \text { cog, CGIC, ADL/IADL, } \\ \text { - Function } & \text { - Collateral Source Geri- mood; heterogenous }\end{array}$ - Variety of cogni- ADAS-Cog
tive skills

$\begin{array}{lll}\text { - Function } & \text { Collateral Source Geri- } & \text { mood; heterogenous } \\ \text { - Mood } & \text { atric Depression Scale, } & \text { results for function }\end{array}$ Montgomery -Asberg

Depression Rating Scale

Kyomen, 2002 PC-RCT [10]

Levine, 2004 Cohort [11]
Women $(\mathrm{n}=14) \quad$ oCEE 0.625

and men $(\mathrm{n}=2) \quad-1.25 \mathrm{mg}-1.875 \mathrm{mg}$

with dementia but $-2.5 \mathrm{mg} /$ day

without other acute (weekly dose

major affective or increase), placebo

psychotic diseases:

no MHT during past

1 month; mean age

83.4 (SD 6.9) yrs.

AD women with ET ET not specified

$(\mathrm{n}=20)$ and

without ET $(\mathrm{n}=79)$;

age $77.5-78.8$ yrs.
4 wks.

- Dementia Signs - Dementia Signs and - CEE significantly and Symptoms

Symptoms scale

- Modified Overt Aggression Scale, MMSE, phys-

ical examinations

At baseline, then weekly.

Assessment only once - Daily functioning • BRDRS (informant) (cross-sectional)

- Clobal dementia MMSE OMC

severity

- NCSE

- Independent

- CSDD

cognitive areas

- NRS

- Depression

- Overall level of

functioning

Symptoms scale (also improved total score and subscores of Dementia Signs and after exclusion of men)

No significant difference on global dementia

severity (MMSE, OMC), overall level of

(cognitive) functioning (NCSE, NRS), depression (CSDD, GDS); significant difference of course of disease (BRDRS): AD women without ET had more "non-memory" problems as initial

symptoms $(\mathrm{p}=0.046)$ and a greater degree of overall behavioral

deficit in activities of daily living at the time of evaluation ( $\mathrm{p}=0.033$ )

(continued on next page) 


Sample size Cohort's

\begin{tabular}{|c|c|c|c|c|}
\hline $\begin{array}{l}\text { Author, year of } \\
\text { publication }\end{array}$ & $\begin{array}{l}\text { Study } \\
\text { design }\end{array}$ & Sample size & $\begin{array}{l}\text { Cohort's } \\
\text { characteristics }\end{array}$ & Intervention \\
\hline $\begin{array}{l}\text { Mulnard, } 2000 \\
\text { [12] }\end{array}$ & PC-RCT & $\begin{array}{l}120 \text { (97 } \\
\text { completed } \\
\text { the trial) }\end{array}$ & $\begin{array}{l}\text { AD women without } \\
\text { uterus; age } 74.1 \\
-76.8 \text { yrs; prior } \\
\text { oophorectomy } 50 \% \\
-69 \% \text {; prior ET use } \\
31 \%-41 \%\end{array}$ & $\begin{array}{l}\text { oCEE } 0.625 \mathrm{mg} / \\
\mathrm{d}(\mathrm{n}=42), \text { oCEE } \\
1.25 \mathrm{mg} / \text { day } \\
(\mathrm{n}=39) \text {, placebo } \\
(\mathrm{n}=39)\end{array}$ \\
\hline
\end{tabular}

Ohkura, 1994 Cohort

[13]
30
AD women; age 71.2 oCEE $1.25 \mathrm{mg} /$ day -71.9 yrs.

$$
\begin{aligned}
& (\mathrm{n}=15), \\
& (\mathrm{n}=15)
\end{aligned}
$$

\begin{tabular}{|c|c|}
\hline $\begin{array}{l}\text { Schneider, } \\
1997 \text { [14] }\end{array}$ & $\begin{array}{l}\text { PC-RCT } \\
\text { (post-hoc } \\
\text { analysis) }\end{array}$ \\
\hline
\end{tabular}

Sundermann, Cohort 2006 [15]
AD women: placebo oCEE (86\%), oE2

$(\mathrm{n}=53), \quad$ (12\%), E1-sulfate placebo + ET $\quad(2 \%)$; mean ET $(\mathrm{n}=7)$, tacrine duration $11 \mathrm{yrs}$; $(\mathrm{n}=50), \quad$ concomitant MPA tacrine + ET $(\mathrm{n}=8)(\mathrm{n}=8)$

AD women with Not specified ever ET for at least
Intervention (post-

Endpoint(a)

Method for endpoint(s)

Results (selection)

intervention Follow-up)

12 months (3 months)

- Global score

assessment

- MMSE, ADAS-cog, CDRS After 12 months of

-

- Memory

- Attention

- Language

- Motor

- Ham-D

reatment no significant

- Emotional Face Recogni- group differences but on

tion Test, New Dot Test CDRS and Finger

- Making Test, Digit

Tapping Test (each

- Activities of Daily Symbol

Living - Category Fluency, Letter Fluency

- Grooved Pegboard Test

Finger Tapping Test

- Blessed Dementia Rating

Scale, Dependency Scale

- MMSE, HDS

- Dementia syn- - GBSS
drome (motor, $\quad$ Ham-D

$\begin{array}{ll}\text { drome (motor, } & \text { - Ham-D } \\ \text { intellectual, } & \text { - SPECT }\end{array}$

emotional func- - Quantitative EEG

tions, different $\quad$ Blood sample

symptoms)

- Depression

- Regional blood

flow

- Brain activity

- Serum steroid

levels

- Global score

- MMSE, ADAS-cog

- Relative change - CIBIC

in subject's

- $\mathrm{CIC}$

global cognitive

and behavioral

status

(physician)

- Relative change

in subject's

Significan

improvement with ET

on MMSE $(\mathrm{p}<0.001)$

HDS $(p<0.01)$, GBSS

$(\mathrm{p}<0.02$ resp. $\mathrm{p}<0.01)$

but return to baseline

values after ET

discontinuation;

significant and

sustained improvement

with ET on Ham-D

$(\mathrm{p}<0.001)$

Significant

improvement with

tacrine + ET on ADAS

$\operatorname{cog}$ (vs. placebo,

$\mathrm{p}=0.009$ ); significant

improvement with

placebo + ET on CIC (vs.

placebo, $\mathrm{p}=0.005$ )

global cognitive

and behavioral

status (caregiver)

Assessment only once - Odor threshold - Two-alternative, forced- No significant

(cross-sectional) 
$1 \mathrm{yr}(\mathrm{n}=24)$ and with never ET

$(\mathrm{n}=77)$; mean age

74 yrs.

\begin{tabular}{|c|c|c|c|c|}
\hline $\begin{array}{l}\text { Wang, } 2000 \\
\text { [16] }\end{array}$ & PC-RCT & 50 & $\begin{array}{l}\text { Mean age } 71 \\
-72.6 \text { yrs. }\end{array}$ & $\begin{array}{l}\text { oCEE } 1.25 \mathrm{mg} / \text { day, } \\
\text { placebo }\end{array}$ \\
\hline
\end{tabular}

- Recognition

memory method of limits with the (odors, faces, symbols) odorant butanol between ET user and

- Standardized test with 15 nonuser; however, ET household odors, 15 pic- nonuser committed tures with faces and 15 significantly more falseabstract symbols, assess- positive errors for ment of number of hits olfactory stimuli than ET

and false-positive errors user (not found for

visual stimuli)

- Cognitive

- CASI

No meaningful

performance

- CDR

differences for any

- CIBIC-plus

outcome.

severity

- BEHAVE

- General clinical • HARS, Ham-D

status

- Common behav-

ioral problems in

AD patients

- Affective

condition

- Regional cerebral

blood flow

Abbreviations: $\mathrm{AD}=$ Alzheimer's disease, $\mathrm{ADAS}-\mathrm{cog}=$ Alzheimer's Disease Assessment Scale-cognitive, BEHAVE-AD = Behavioral Pathology in Alzheimer's Disease, $\mathrm{BMI}=$ Body Mass Index, $\mathrm{BMICT}=$ Blessed Memory Information and Concentration Test, BNT $=$ Boston Naming Test, BPRS = Brief Psychiatric Rating Scale, BRDRS $=$ Blessed Roth Dementia Rating Scale, CASI = Cognitive Ability Screening Instrument, CDRS $=$ Clinical Dementia Rating Scale, CEE $=$ conjugated equine estrogens, CERAD $=$ Consortium to Establish a Registry for AD, CGIC $=$ Clinical Global Impression of Change, CIBIC = Clinician-rated, Interview-based Impression of Change, CIC = Caregiver's Impression of Change, CSDD $=$ Cornell Scale of Depression in Dementia, $\mathrm{DSB}=$ digit span backward, DSF = digit span forward, E1 = estrone, E2 = 17beta-estradiol, EEG = quantitative electroencepahologram, ET = estrogen therapy, GBS = Gottfries $-\mathrm{Brane}-\mathrm{Steen}$ Scale, GDS = Geriatric Depression Scale, HARS $=$ Hamilton Anxiety Rating Scale, Ham-D = Hamilton Depression Rating Scale, HDS $=$ Hasegawa Dementia Scale, IADL $=$ Instrumental Activities of Daily Living, MHT = Menopausal Hormone Therapy, MMSE = Mini-Mental State Examination, MPA = medroxyprogesterone acetate, NCSE $=$ Neurocognitive Status Exam, NRS $=$ Neuropsychological Rating Scale, $\mathrm{o}=$ oral, OMC = Orientation-memory-concentration test, PC-RCT = Placebo-controlled randomized trial, PSMS $=$ Physical Self-Maintenance Scale, SD = Standard Deviation, SPECT $=$ Single Photon Emission Computed Tomography, $\mathrm{t}=$ transdermal, $\mathrm{VMSB}=$ visual memory span backward, $\mathrm{VMSF}=\mathrm{visual}$ memory span forward, wk $=$ week, yrs. $=$ years. 
Table 4

Risk factors for dementia (only statistically significant risk factors that appeared in more than two studies were included; modified according to [1]).

\begin{tabular}{|c|c|c|c|c|}
\hline Factor & Metric & Effect size $(95 \% \mathrm{CI})$ & Neurological condition & Level of Evidence \\
\hline \multirow[t]{3}{*}{ Type 2 diabetes mellitus } & RR & $1.54(1.39-1.72)$ & $\mathrm{AD}$ & Convincig \\
\hline & RR & $1.60(1.43-1.79)$ & Dementia & Highly suggestive \\
\hline & RR & $2.28(1.94-2.66)$ & Vascular dementia & Convincing \\
\hline Hypertension & HR & $1.59(1.20-2.11)$ & Vascular dementia & Weak \\
\hline \multirow[t]{2}{*}{ Smoking } & RR & $1.26(1.05-1.50)$ & Vascular dementia & Weak \\
\hline & RR & $1.13(1.05-1.22)$ & Dementia & Weak \\
\hline Low-frequency electromagnetic fields & RR & $1.74(1.37-2.21)$ & $\mathrm{AD}$ & Suggestive \\
\hline \multirow[t]{2}{*}{ Midlife BMI (obese versus normal weight) } & RR & $1.81(1.22-2.69)$ & $\mathrm{AD}$ & Weak \\
\hline & $\mathrm{RR}$ & $1.91(1.40-2.62)$ & Dementia & Suggestive \\
\hline \multirow[t]{2}{*}{ Mild traumatic brain injury } & OR & $1.35(1.01-1.78)$ & Dementia & Weak \\
\hline & OR & $1.40(1.03-1.90)$ & $\mathrm{AD}$ & Weak \\
\hline \multirow{3}{*}{ Depression at any age/stage } & RR & $1.99(1.84-2.16)$ & Dementia & Convincing \\
\hline & $\mathrm{RR}$ & $2.92(1.87-4.56)$ & Vascular dementia & Weak \\
\hline & $\mathrm{RR}$ & $1.77(1.48-2.13)$ & $\mathrm{AD}$ & Highly suggestive \\
\hline Early life depression & RR & $1.63(1.27-2.11)$ & Dementia & Suggestive \\
\hline \multirow[t]{3}{*}{ Late life depression } & $\mathrm{RR}$ & $1.85(1.67-2.05)$ & Dementia & Convincing \\
\hline & OR & $2.52(1.77-3.59)$ & Vascular dementia & Weak \\
\hline & RR & $1.65(1.42-1.92)$ & $\mathrm{AD}$ & Convincing \\
\hline \multirow[t]{3}{*}{ Low level of education (versus high level) } & RR & $1.88(1.51-2.33)$ & Dementia & Suggestive \\
\hline & RR & $2.75(2.19-3.45)$ & Vascular dementia & Weak \\
\hline & $\mathrm{RR}$ & $1.82(1.36-2.43)$ & $\mathrm{AD}$ & Suggestive \\
\hline Frequency of social contacts (low versus high level) & RR & $1.57(1.32-1.85)$ & Dementia & Convincing \\
\hline Loneliness & RR & $1.58(1.19-2.09)$ & Dementia & Weak \\
\hline Neuroticism (high versus low level) & HR & $1.33(1.21-1.45)$ & $\mathrm{AD}$ & Weak \\
\hline Aluminium (exposed versus not exposed) & OR & $1.72(1.33-2.21)$ & $\mathrm{AD}$ & Suggestive \\
\hline
\end{tabular}

Definitions: "convincing" = statistical significance according to random-effects model at $\mathrm{P}<10-6$; based on more than 1000 cases; without large between-study heterogeneity (I2<50\%); 95\% PI excluding the null value; and no evidence of small-study effects and excess significance; "highly suggestive" = associations with $>1000$ cases, $\mathrm{P}<10-6$, and largest study presenting a statistically significant effect; "suggestive" $=$ associations with $>1000$ cases and a significant effect at $\mathrm{P}<10-3$; "weak" = remaining nominally significant associations.

Abbreviations: $\mathrm{AD}=$ Alzheimer's disease, $\mathrm{BMI}=$ Body Mass Index, $\mathrm{CI}=$ confidence interval, $\mathrm{HR}=$ hazard ratio, $\mathrm{OR}=$ odds ratio, $\mathrm{RR}=$ relative risk

Table 5

Protective factors for dementia (only statistically significant risk factors that appeared in more than two studies were included; modified according to [1]).

\begin{tabular}{|c|c|c|c|c|}
\hline Factor & Metric & Effect size $(95 \% \mathrm{CI})$ & Neurological condition & $\begin{array}{l}\text { Level of } \\
\text { Evidence }\end{array}$ \\
\hline \multirow[t]{2}{*}{ Mediterranean diet } & RR & $0.60(0.48-0.77)$ & $\mathrm{AD}$ & IV \\
\hline & $\mathrm{RR}$ & $0.69(0.57-0.84)$ & Dementia & Convincing \\
\hline Coffee consumption & $\mathrm{RR}$ & $0.73(0.55-0.97)$ & $\mathrm{AD}$ & Possible \\
\hline \multirow[t]{3}{*}{ Alcohol intake (light or moderate versus never } & $\mathrm{RR}$ & $0.74(0.61-0.91)$ & Dementia & Weak \\
\hline & $\mathrm{RR}$ & $0.75(0.57-0.98)$ & Vascular dementia & Weak \\
\hline & $\mathrm{RR}$ & $0.72(0.61-0.86)$ & $\mathrm{AD}$ & Weak \\
\hline \multirow[t]{3}{*}{ Physical activity (high level versus low level) } & $\mathrm{RR}$ & $0.76(0.66-0.86)$ & Dementia & Suggestive \\
\hline & $\mathrm{RR}$ & $0.62(0.42-0.92)$ & Vascular dementia & Weak \\
\hline & HR & $0.62(0.52-0.72)$ & $\mathrm{AD}$ & $\begin{array}{l}\text { Highly } \\
\text { suggestive }\end{array}$ \\
\hline Vitamin E dietary intake (high versus low) & RR & $0.80(0.67-0.95)$ & $\mathrm{AD}$ & Weak \\
\hline Vitamin C dietary intake (high versus low) & RR & $0.85(0.74-0.96)$ & $\mathrm{AD}$ & Weak \\
\hline \multirow[t]{2}{*}{ Statins (ever versus never use) } & $\mathrm{RR}$ & $0.83(0.76-0.91)$ & Dementia & Sugegstive \\
\hline & $\mathrm{RR}$ & $0.72(0.59-0.89)$ & $\mathrm{AD}$ & Weak \\
\hline \multirow[t]{2}{*}{ Antihypertensive drugs (ever versus never use) } & HR & $0.84(0.75-0.94)$ & Dementia & Weak \\
\hline & RR & $0.64(0.42-0.98)$ & Vascular dementia & Weak \\
\hline Aspirin (ever versus never use) & $\mathrm{RR}$ & $0.77(0.63-0.95)$ & $\mathrm{AD}$ & Weak \\
\hline NSAIDS (ever versus never use) & $\mathrm{RR}$ & $0.74(0.64-0.86)$ & $\mathrm{AD}$ & Suggestive \\
\hline Fish intake (high versus low) & RR & $0.88(0.79-0.98)$ & $\mathrm{AD}$ & Weak \\
\hline
\end{tabular}


Table 5 (continued)

\begin{tabular}{lllll}
\hline Factor & Metric & Effect size (95\% CI) & Neurological condition & $\begin{array}{l}\text { Level of } \\
\text { Evidence }\end{array}$ \\
\hline Openness (high versus low level) & RR & $0.86(0.77-0.96)$ & AD & Weak \\
\hline
\end{tabular}

Definitions: "convincing" = statistical significance according to random-effects model at $\mathrm{P}<10-6$; based on more than 1000 cases; without large between-study heterogeneity (I2<50\%); 95\% PI excluding the null value; and no evidence of small-study effects and excess significance; "highly suggestive" = associations with $>1000$ cases, $\mathrm{P}<10-6$, and largest study presenting a statistically significant effect; "suggestive" = associations with $>1000$ cases and a significant effect at $\mathrm{P}<10-3$; "weak" = remaining nominally significant associations.

Abbreviations: $\mathrm{AD}=$ Alzheimer's disease, $\mathrm{CI}=$ confidence interval, $\mathrm{HR}=$ hazard ratio, NSAIDS $=$ Non-steroidal anti-inflammatory drugs, $\mathrm{RR}=$ relative risk.

Table 6

Impact of estrogens on risk and protective factors for $\mathrm{AD} /$ dementia.

\begin{tabular}{|c|c|}
\hline $\begin{array}{l}\text { Protective Factors for } \\
\text { developing dementia/ } \\
\text { AD }\end{array}$ & Role of estrogens (examples) \\
\hline Mediterranean diet & $\begin{array}{l}\text { Possibly synergistic effect with estrogens as mediterranean diet may improve vasomotor } \\
\text { symptoms, cardiovascular risk factors, mood and symptoms of depression. Long-term adherence } \\
\text { may improve cardiovascular risk, bone mineral density and prevent cognitive decline [1]. }\end{array}$ \\
\hline Coffee consumption & $\begin{array}{l}\text { Possibly synergistic effect with estrogens as bioactive substances from coffee have been shown to } \\
\text { enhance glucose uptake in muscle cells in a dose-dependent manner in vitro, suggesting a } \\
\text { preventive effect on T2DM in coffee drinkers [2]. }\end{array}$ \\
\hline Alcohol intake & $\begin{array}{l}\text { Higher alcohol intake has been shown to be associated with higher serum E2 levels (post-hoc } \\
\text { analysis of the RCT ELITE) [83]. }\end{array}$ \\
\hline Physical activity & $\begin{array}{l}\text { Women with premature ovarian insufficiency experience significant deterioration in } \\
\text { musculoskeletal health due to the loss of protective effects of estrogen [4]. } \\
\text { Estrogens may regulate muscle mass and strength [5]. } \\
\text { Decreased estrogen level occurring at menopause is linked to decreased energy expenditure [6]. } \\
\text { Spontaneous physical activity has been shown to be reduced in OVX mice [6]. }\end{array}$ \\
\hline $\begin{array}{l}\text { Vitamin E and C dietary } \\
\text { intake }\end{array}$ & $\begin{array}{l}\text { Positive associations between serum antioxidants (including vitamin E and C) and endogenous } \\
\text { hormones (E2, progesterone, testosterone) have been reported in healthy premenopausal women } \\
\text { supporting the hypothesis that concentrations of serum vitamins affect steroidogenesis [7]. }\end{array}$ \\
\hline Statins & Synergistic effect with estrogens also lowering serum lipids [8]. \\
\hline Antihypertensive drugs & $\begin{array}{l}\text { Synergistic effect with estrogens as transdermal estrogens have been shown to have a beneficial } \\
\text { effect on blood pressure in normotensive women and, at most, a neutral effect on hypertensive } \\
\text { women. Oral estrogens had a neutral effect on blood pressure in hypertensive women [9]. }\end{array}$ \\
\hline Fish intake & $\begin{array}{l}\text { Possibly synergistic effect with estrogens: the essential fatty acid ALA) is converted into longer- } \\
\text { chain fatty acids including EPA, DPA and DHA. Women have been shown to reach greater increases } \\
\text { in EPA status after ALA supplementation than men, supporting animal studies that have identified } \\
\text { mechanisms by which sex hormones such as estrogen and progesterone interact with the synthesis } \\
\text { of EPA and DHA [10]. }\end{array}$ \\
\hline $\begin{array}{l}\text { Openness (high versus } \\
\text { low level) }\end{array}$ & $\begin{array}{l}\text { Possibly synergistic effect with estrogens as estrogens may reduce risk of depression in } \\
\text { perimenopausal women [11]. }\end{array}$ \\
\hline $\begin{array}{l}\text { Risk Factors for } \\
\text { developing } \\
\text { dementia/AD }\end{array}$ & Effect of estrogens (examples) \\
\hline
\end{tabular}

\begin{tabular}{|c|c|}
\hline T2DM & Significant risk reduction for developing T2DM [12]. \\
\hline Hypertension & See section above on „antihypertensive drugs” \\
\hline Midlife BMI & MHT has a neutral or beneficial effect on BMI [13]. \\
\hline $\begin{array}{l}\text { Mild traumatic brain } \\
\text { injury }\end{array}$ & E2 has a neuroprotective role in brain injury $[84,85]$. \\
\hline Depression & MHT may reduce risk of depression in perimenopausal women [11]. \\
\hline $\begin{array}{l}\text { Frequency of social } \\
\text { contacts }\end{array}$ & $\begin{array}{l}\text { In rodents, estrogens have been shown to play an important role in the regulation of social } \\
\text { behavior, from the production and detection of social signals to the expression of social } \\
\text { preferences, social recognition, social learning and aggression [16]. }\end{array}$ \\
\hline Loneliness & $\begin{array}{l}\text { As MHT may reduce risk of depression in perimenopausal women [11] the feeling of loneliness may } \\
\text { also decrease. }\end{array}$ \\
\hline Neuroticism & $\begin{array}{l}\text { Estrogens have psychotropic properties such as increase in extraversion and decrease in } \\
\text { neuroticism according to the Eysenck Personality Model [17]. }\end{array}$ \\
\hline
\end{tabular}

Abbreviations:AD = Alzheimer's disease, ALA $=\alpha$-linolenic acid, BMI $=$ Body Mass Index, DHA $=$ docosahexaenoic acid, $\mathrm{DPA}=$ docosapentaenoic acid, E2 = estradiol, ELITE $=$ Early versus Late Intervention Trial with Estradiol, EPA = eicosapentaenoic acid, $\mathrm{MHT}=$ Menopausal Hormone Therapy, OVX = ovariectomy, RCT $=$ randomized controlled trial, T2DM $=$ type 2 diabetes mellitus. 
Dementia is a chronic non-communicable disease (NCD). Alzheimer's disease (AD) is the most common cause of dementia.

Lifetime risk for developing $\mathrm{AD}$ is $\mathbf{1 0}$ in $\mathbf{1 0 0}$ women aged $\mathbf{6 5}+$

Risk factors: age, disposition (family history, genetic mutations, polymorphism of APOE gene) and exposition (behaviour, environment).

\begin{tabular}{|c|c|c|}
\hline \multirow{3}{*}{$\begin{array}{l}\text { Menopausal Hormone Therapy } \\
\text { reduces risk for dementia / AD by }\end{array}$} & Acquired risk factors & Acquired protective factors \\
\hline & Type 2 diabetes mellitus** & Mediterranean diet** \\
\hline & Hypertension** & Coffee consumption** \\
\hline \multirow[t]{2}{*}{$11 \%^{1}-33 \%^{2}$} & Smoking & Light/moderate alcohol intake \\
\hline & Low-frequency electromagnetic fields & Physical activity (high level) ${ }^{* *}$ \\
\hline \multirow{4}{*}{$\begin{array}{l}\text { Menopausal Hormone Therapy } \\
\text { has a beneficial / supporting effect on }\end{array}$} & Midlife obesity** & Vitamin $\mathrm{E}$ dietary intake** \\
\hline & Mild traumatic brain injury** & Vitamin $\mathrm{C}$ dietary intake** \\
\hline & Depression** & $\begin{array}{c}\text { Drugs: Statins, antihypertensive drugs, } \\
\text { Aspirin, NSAIDS**, } \\
\text { Menopausal Hormone Therapy }\end{array}$ \\
\hline & Low level of education & Fish intake** \\
\hline (marked oy $)$ & $\begin{array}{l}\text { Low frequency of social contacts, } \\
\text { loneliness** }\end{array}$ & Openness** \\
\hline
\end{tabular}

'Wu, M., et al., Postmenopausal hormone therapy and Alzheimer's disease, dementia, and Parkinson's disease: A systematic review and time-response meta-analysis. Pharmacol Res, 2020. (prospective studies only)

Fig. 1. Counseling tool for daily practice.

mentioned before (Table 6). For example, estrogens may have synergistically protective effects with certain lifestyle factors (Mediterranean diet [69], coffee consumption [70]), and drugs (micronutrients [71,72], statins [73], antihypertensive drugs [74]). Furthermore, estrogens may maintain or support physical activity [75-77] and personality traits [78]. Similarly, estrogens may counteract risk factors for $\mathrm{AD}$ and dementia, e.g. T2DM [79], hypertension [74], overweight/obesity [80], affective disorders [78,81,82]. Fig. 1 summarizes the above mentioned data and provides a counseling tool for daily practice.

\section{Practice points}

- 10 in 100 women above age 65 will be diagnosed with dementia/Alzheimer's disease.

- Apart from age and hereditary risk factors, there are multiple acquired risk and protective factors.

- Overall, menopausal hormone therapy may reduce the risk of dementia/Alzheimer's disease by about $11-33 \%$. However, risk may vary depending on MHT type and age at initiation.

- Menopausal hormone therapy also displays a beneficial effect on some dementia risk factors and also augments some protective factors.

- Menopausal hormone therapy is not indicated for cognitive improvement in demented women.

\section{Research agenda}

- Impact of different hormone types, regimens and dosages on dementia/AD risk, e.g. bioidentical hormones (estradiol, micronized progesterone, dehydroepiandrosterone, testosterone), transdermal versus oral application, ultralow-dose versus standard-dose MHT.

- Defining the optimal age for MHT initiation and optimal MHT duration.

- Clarification, if there is a cognitive "window of opportunity" or not.

- Update of international scientific guidelines on MHT. 


\section{Summary}

Dementia is a pandemic chronic non-communicable disease. 10 in 100 women above age 65 will be diagnosed with dementia, primarily Alzheimer's disease (AD). Apart from age and hereditary risk factors, there are multiple acquired risk and protective factors. Menopausal hormone therapy (MHT) reduces the risk of dementia/AD by about $11-33 \%$. However, results may vary depending on MHT type, age at initiation and study design. For example, the Women's Health Initiative Memory Study (WHIMS) reported an approximately 2-fold increased risk of dementia/Alzheimer's disease if MHT comprising conjugated equine estrogens and medroxyprogesterone acetate was initiated in predominantly comorbid postmenopausal women above age 65. MHT also displays a beneficial effect on some dementia risk factors and also supports some protective factors. MHT is not indicated for cognitive improvement in demented women. International scientific guidelines on MHT and dementia should acknowledge most recent data, including systematic reviews and meta-analyses.

\section{Declaration of competing interest}

The authors declare to have no conflict of interest in respect to the content of this publication.

\section{Acknowledgments}

The authors would like to thank Ms Daniela Hostettler, secretary, for ordering all full-articles identified by the systematic literature search. This work was funded bei thirdfunds of Petra Stute.

\section{Appendix A. Supplementary data}

Supplementary data to this article can be found online at https://doi.org/10.1016/j.beem.2021. 101565.

\section{References}

[1] Livingston G, Sommerlad A, Orgeta V, et al. Dementia prevention, intervention, and care. Lancet 2017;390(10113): 2673-734.

[2] Dubal DB. Sex difference in Alzheimer's disease: an updated, balanced and emerging perspective on differing vulnerabilities. Handb Clin Neurol 2020;175:261-73.

[3] Alzheimer-Europe., Prevalence of dementia in europe. www.alzheimer-europe.org/EN/Research/EuropeanCollaborationon-Dementia/Prevalence-of-dementia/Prevalence-of-dementia-in-Europe. 2020: www.alzheimer-europe.org/EN/ Research/EuropeanCollaboration-on-Dementia/Prevalence-of-dementia/ Prevalence-of-dementia-in-Europe.

[4] Sarri G, Davies M, Lumsden MA, G. Guideline Development. Diagnosis and management of menopause: summary of NICE guidance. BMJ 2015;351:h5746.

[5] Baber RJ, Panay N, Fenton ATIWG. 2016 IMS Recommendations on women's midlife health and menopause hormone therapy. Climacteric 2016;19(2):109-50.

*[6] Armeni E, Lambrinoudaki I, Ceausu I, et al. Maintaining postreproductive health: a care pathway from the European Menopause and Andropause Society (EMAS). Maturitas 2016;89:63-72.

*[7] The 2017 hormone therapy position statement of the North American Menopause Society. Menopause 2017;24(7): $728-53$.

*[8] Wu M, Li M, Yuan J, et al. Postmenopausal hormone therapy and Alzheimer’s disease, dementia, and Parkinson's disease: a systematic review and time-response meta-analysis. Pharmacol Res 2020;155:104693.

[9] LeBlanc ES, Janowsky J, Chan BK, et al. Hormone replacement therapy and cognition: systematic review and meta-analysis. Jama 2001;285(11):1489-99.

*[10] Song YJ, Li SR, Li XW, et al. The effect of estrogen replacement therapy on alzheimer's disease and Parkinson's disease in postmenopausal women: a meta-analysis. Front Neurosci 2020;14:157.

[11] Hogervorst E, Williams J, Budge M, et al. The nature of the effect of female gonadal hormone replacement therapy on cognitive function in post-menopausal women: a meta-analysis. Neuroscience 2000;101(3):485-512.

[12] Han M, Chang J, Choi S, et al. Association of tibolone and dementia risk: a cohort study using Korean claims data. Gynecol Endocrinol 2020:1-5.

[13] Paganini-Hill A, Corrada MM, Kawas CH. Prior endogenous and exogenous estrogen and incident dementia in the 10th decade of life: the 90+ Study. Climacteric 2020;23(3):311-5.

[14] Yoo JE, Shin DW, Han K, et al. Female reproductive factors and the risk of dementia: a nationwide cohort study. Eur J Neurol 2020;27(8):1448-58.

[15] Savolainen-Peltonen H, Rahkola-Soisalo P, Hoti F, et al. Use of postmenopausal hormone therapy and risk of Alzheimer's disease in Finland: nationwide case-control study. BMJ 2019;364:1665. 
[16] Imtiaz B, Taipale H, Tanskanen A, et al. Risk of Alzheimer's disease among users of postmenopausal hormone therapy: a nationwide case-control study. Maturitas 2017;98:7-13.

[17] Imtiaz B, Tuppurainen M, Rikkonen T, et al. Postmenopausal hormone therapy and Alzheimer disease: a prospective cohort study. Neurology 2017;88(11):1062-8.

[18] Lindsay J, Laurin D, Verreault R, et al. Risk factors for Alzheimer's disease: a prospective analysis from the Canadian Study of Health and Aging. Am J Epidemiol 2002;156(5):445-53.

[19] Shao H, Breitner JC, Whitmer RA, et al. Hormone therapy and Alzheimer disease dementia: new findings from the Cache County Study. Neurology 2012;79(18):1846-52.

[20] Ryan J, Carrière I, Scali J, et al. Characteristics of hormone therapy, cognitive function, and dementia: the prospective 3C Study. Neurology 2009;73(21):1729-37.

[21] Roberts RO, Cha RH, Knopman DS, et al. Postmenopausal estrogen therapy and Alzheimer disease: overall negative findings. Alzheimer Dis Assoc Disord 2006;20(3):141-6.

[22] Seshadri S, Zornberg GL, Derby LE, et al. Postmenopausal estrogen replacement therapy and the risk of Alzheimer disease. Arch Neurol 2001;58(3):435-40.

[23] Waring SC, Rocca WA, Petersen RC, et al. Postmenopausal estrogen replacement therapy and risk of AD: a populationbased study. Neurology 1999;52(5):965-70.

[24] Kawas C, Resnick S, Morrison A, et al. A prospective study of estrogen replacement therapy and the risk of developing Alzheimer's disease: the Baltimore Longitudinal Study of Aging. Neurology 1997;48(6):1517-21.

[25] Baldereschi M, Di Carlo A, Lepore V, et al. Estrogen-replacement therapy and alzheimer's disease in the Italian longitudinal study on aging. Neurology 1998;50(4):996-1002.

[26] Tang MX, Jacobs D, Stern Y, et al. Effect of oestrogen during menopause on risk and age at onset of Alzheimer's disease. Lancet 1996;348(9025):429-32.

[27] Paganini-Hill A, Henderson VW. Estrogen replacement therapy and risk of Alzheimer disease. Arch Intern Med 1996; 156(19):2213-7.

[28] Brenner DE, Kukull WA, Stergachis A, et al. Postmenopausal estrogen replacement therapy and the risk of Alzheimer's disease: a population-based case-control study. Am J Epidemiol 1994;140(3):262-7.

[29] Espeland MA, Brinton RD, Hugenschmidt C, et al. Impact of type 2 diabetes and postmenopausal hormone therapy on incidence of cognitive impairment in older women. Diabetes Care 2015;38(12):2316-24.

*[30] Manson JE, Chlebowski RT, Stefanick ML, et al. Menopausal hormone therapy and health outcomes during the intervention and extended poststopping phases of the Women's Health Initiative randomized trials. J Am Med Assoc 2013;310(13): 1353-68.

[31] Whitmer RA, Quesenberry CP, Zhou J, et al. Timing of hormone therapy and dementia: the critical window theory revisited. Ann Neurol 2011;69(1):163-9.

[32] Petitti DB, Crooks VC, Chiu V, et al. Incidence of dementia in long-term hormone users. Am J Epidemiol 2008;167(6): $692-700$.

[33] Broe GA, Henderson AS, Creasey H, et al. A case-control study of Alzheimer's disease in Australia. Neurology 1990;40(11): $1698-707$.

[34] Graves AB, White E, Koepsell TD, et al. A case-control study of Alzheimer's disease. Ann Neurol 1990;28(6):766-74.

[35] Paganini-Hill A, Henderson VW. Estrogen deficiency and risk of Alzheimer's disease in women. Am J Epidemiol 1994; 140(3):256-61.

[36] Mortel KF, Meyer JS. Lack of postmenopausal estrogen replacement therapy and the risk of dementia. J Neuropsychiatry Clin Neurosci 1995;7(3):334-7.

[37] Slooter AJ, Bronzova J, Witteman JC, et al. Estrogen use and early onset Alzheimer's disease: a population-based study. J Neurol Neurosurg Psychiatry 1999;67(6):779-81.

[38] Zandi PP, Carlson MC, Plassman BL, et al. Hormone replacement therapy and incidence of Alzheimer disease in older women: the Cache County Study. J Am Med Assoc 2002;288(17):2123-9.

[39] Henderson VW, Benke KS, Green RC, et al. Postmenopausal hormone therapy and Alzheimer's disease risk: interaction with age. J Neurol Neurosurg Psychiatry 2005;76(1):103-5.

[40] Lau DT, Mercaldo ND, Harris AT, et al. Polypharmacy and potentially inappropriate medication use among communitydwelling elders with dementia. Alzheimer Dis Assoc Disord 2010;24(1):56-63.

[41] Levine AJ, Hewett L. Estrogen replacement therapy and frontotemporal dementia. Maturitas 2003;45(2):83-8

[42] Mikkola TS, Savolainen-Peltonen H, Tuomikoski P, et al. Lower death risk for vascular dementia than for alzheimer's disease with postmenopausal hormone therapy users. J Clin Endocrinol Metab 2017;102(3):870-7.

*[43] Shumaker SA, Legault C, Rapp SR, et al. Estrogen plus progestin and the incidence of dementia and mild cognitive impairment in postmenopausal women: the Women's Health Initiative Memory Study: a randomized controlled trial. Jama 2003;289(20):2651-62.

*[44] Shumaker SA, Legault C, Kuller L, et al. Conjugated equine estrogens and incidence of probable dementia and mild cognitive impairment in postmenopausal women: women's Health Initiative Memory Study. Jama 2004;291(24): 2947-58.

[45] Zucchella C, Sinforiani E, Citterio A, et al. Reproductive life events and Alzheimer's disease in Italian women: a retrospective study. Neuropsychiatric Dis Treat 2012;8:555-60.

[46] Shao H, Breitner JC, Whitmer RA, et al. Hormone therapy and Alzheimer disease dementia: new findings from the Cache County Study. Neurology 2012;79(18):1846-52.

[47] Daniel JM. Estrogens, estrogen receptors, and female cognitive aging: the impact of timing. Horm Behav 2013;63(2):231-7.

*[48] Henderson VW. Alzheimer's disease: review of hormone therapy trials and implications for treatment and prevention after menopause. J Steroid Biochem Mol Biol 2014;142:99-106.

[49] Kantarci K, Lowe VJ, Lesnick TG, et al. Early postmenopausal transdermal 17 $\beta$-estradiol therapy and amyloid- $\beta$ deposition. J Alzheimers Dis 2016;53(2):547-56. 
[50] Asthana S, Craft S, Baker LD, et al. Cognitive and neuroendocrine response to transdermal estrogen in postmenopausal women with Alzheimer's disease: results of a placebo-controlled, double-blind, pilot study. Psychoneuroendocrinology 1999;24(6):657-77.

[51] Asthana S, Baker LD, Craft S, et al. High-dose estradiol improves cognition for women with AD: results of a randomized study. Neurology 2001;57(4):605-12.

[52] Fillit H, Weinreb H, Cholst I, et al. Observations in a preliminary open trial of estradiol therapy for senile dementia-Alzheimer's type. Psychoneuroendocrinology 1986;11(3):337-45.

[53] Fillit H. Estrogens in the pathogenesis and treatment of Alzheimer's disease in postmenopausal women. Ann N Y Acad Sci 1994;743:233-8. discussion 238-9.

[54] Henderson VW, Paganini-Hill A, Emanuel CK, et al. Estrogen replacement therapy in older women. Comparisons between Alzheimer's disease cases and nondemented control subjects. Arch Neurol 1994;51(9):896-900.

[55] Henderson VW, Watt L, Buckwalter JG. Cognitive skills associated with estrogen replacement in women with Alzheimer's disease. Psychoneuroendocrinology 1996;21(4):421-30.

[56] Henderson VW, Paganini-Hill A, Miller BL, et al. Estrogen for Alzheimer's disease in women: randomized, double-blind, placebo-controlled trial. Neurology 2000;54(2):295-301.

[57] Kyomen HH, Hennen J, Gottlieb GL, et al. Estrogen therapy and noncognitive psychiatric signs and symptoms in elderly patients with dementia. Am J Psychiatr 2002;159(7):1225-7.

[58] Levine AJ, Battista M. Estrogen replacement therapy: effects on the cognitive functioning and clinical course of women with Alzheimer's disease. Arch Clin Neuropsychol 2004;19(6):769-78.

[59] Mulnard RA, Cotman CW, Kawas C, et al. Estrogen replacement therapy for treatment of mild to moderate Alzheimer disease: a randomized controlled trial. Alzheimer's Disease Cooperative Study. Jama 2000;283(8):1007-15.

[60] Ohkura T, Isse K, Akazawa K, et al. Evaluation of estrogen treatment in female patients with dementia of the Alzheimer type. Endocr J 1994;41(4):361-71.

[61] Schneider LS, Farlow MR, Pogoda JM. Potential role for estrogen replacement in the treatment of Alzheimer's dementia. Am J Med 1997;103(3a):46s-50s.

[62] Sundermann E, Gilbert PE, Murphy C. Estrogen and performance in recognition memory for olfactory and visual stimuli in females diagnosed with Alzheimer's disease. J Int Neuropsychol Soc 2006;12(3):400-4.

[63] Wang PN, Liao SQ Liu RS, et al. Effects of estrogen on cognition, mood, and cerebral blood flow in AD: a controlled study. Neurology 2000;54(11):2061-6.

*[64] Hogervorst E, Yaffe K, Richards M, et al. Hormone replacement therapy to maintain cognitive function in women with dementia. Cochrane Database Syst Rev 2009;(1). CD003799.

*[65] Stute P, Ceausu I, Depypere H, et al. A model of care for healthy menopause and ageing: EMAS position statement. Maturitas 2016;92:1-6.

[66] Mentis AA, Dardiotis E, Efthymiou V, et al. Non-genetic risk and protective factors and biomarkers for neurological disorders: a meta-umbrella systematic review of umbrella reviews. BMC Med 2021;19(1):6.

[67] Kuhl H. Pharmacology of progestogens. J Reproduktionsmed Endokrinol 2011;8.

[68] Uddin MS, Rahman MM, Jakaria M, et al. Estrogen signaling in alzheimer's disease: molecular insights and therapeutic targets for alzheimer's dementia. Mol Neurobiol 2020;57(6):2654-70.

[69] Cano A, Marshall S, Zolfaroli I, et al. The Mediterranean diet and menopausal health: an EMAS position statement. Maturitas 2020;139:90-7.

[70] Mellbye FB, Jeppesen PB, Hermansen K, et al. Cafestol, a bioactive substance in coffee, stimulates insulin secretion and increases glucose uptake in muscle cells: studies in vitro. J Nat Prod 2015;78(10):2447-51.

[71] Mumford SL, Browne RW, Schliep KC, et al. Serum antioxidants are associated with serum reproductive hormones and ovulation among healthy women. J Nutr 2016;146(1):98-106.

[72] Childs CE. Sex hormones and. Proc Nutr Soc 2020;79(2):219-24.

[73] Walsh BW, Schiff I, Rosner B, et al. Effects of postmenopausal estrogen replacement on the concentrations and metabolism of plasma lipoproteins. N Engl J Med 1991;325(17):1196-204.

[74] Issa Z, Seely EW, Rahme M, et al. Effects of hormone therapy on blood pressure. Menopause 2015;22(4):456-68.

[75] Samad N, Nguyen HH, Scott D, et al. Musculoskeletal health in premature ovarian insufficiency. Part One: muscle. Semin Reprod Med 2020;38(4-5):277-88.

[76] Alexander SE, Pollock AC, Lamon S. The effect of sex hormones on skeletal muscle adaptation in females. Eur J Sport Sci 2021:1-11.

[77] Chalvon-Demersay T, Blachier F, Tomé D, et al. Animal models for the study of the relationships between diet and obesity: a focus on dietary protein and estrogen deficiency. Front Nutr 2017;4:5.

[78] Stute P, Spyropoulou A, Karageorgiou V, et al. Management of depressive symptoms in peri- and postmenopausal women: EMAS position statement. Maturitas 2020;131:91-101.

[79] NIfHaC E. Menopause: diagnosis and management of menopause. NICE guideline; 2015.

[80] Coquoz A, Gruetter C, Stute P. Impact of micronized progesterone on body weight, body mass index, and glucose metabolism: a systematic review. Climacteric 2018:1-14.

[81] Ervin KS, Lymer JM, Matta R, et al. Estrogen involvement in social behavior in rodents: rapid and long-term actions. Horm Behav 2015;74:53-76.

[82] Herrmann WM, Beach RC. The psychotropic properties of estrogens. Pharmakopsychiatr Neuro-Psychopharmakol 1978; 11(4):164-76.

[83] Sriprasert I, Kono N, Karim R, et al. Factors associated with serum estradiol levels among postmenopausal women using hormone therapy. Obstet Gynecol 2020;136(4):675-84.

[84] Kövesdi E, Szabó-Meleg E, Abrahám IM. The role of estradiol in traumatic brain injury: mechanism and treatment potential. Int J Mol Sci 2020;22(1).

[85] Wang J, Hou Y, Zhang L, et al. Estrogen attenuates traumatic brain injury by inhibiting the activation of microglia and astrocyte-mediated neuroinflammatory responses. Mol Neurobiol 2021;58(3):1052-61. 